\title{
Urban sprawl and land abandonment affect the functional response traits of maize weed communities in a heterogeneous landscape
}

\author{
Stefano Carlesi, Gionata Bocci, Anna-Camilla Moonen*, Paolo Frumento, Paolo Bàrberi \\ Institute of Life Sciences, Scuola Superiore Sant'Anna, Piazza Martiri della Libertà 33, 56127 Pisa, Italy
}

\section{A R T I C L E I N F O}

\section{Article history:}

Received 12 March 2012

Received in revised form 1 December 2012

Accepted 29 December 2012

Available online 4 February 2013

\section{Keywords:}

Species richness

Farming practices

Field margin

Generalised additive model

Mediterranean

Semi-natural vegetation

\begin{abstract}
A B S T R A C T
Landscape effects on arable weed communities have mainly been studied in areas dominated by intensive agricultural land use, while less attention has been paid to the same effects in cultivated fields close to the rural-urban interface. Our objective was to assess the effects of ongoing agricultural land abandonment and urban sprawl on arable weed communities since this is a widespread phenomena in Mediterranean landscapes.

Weeds were sampled at three different distances $(5,10,15 \mathrm{~m})$ from the field margin in 21 maize fields located within a $75 \mathrm{~km}^{2}$ area in Liguria and Tuscany, Italy. Species were aggregated in functional response groups based on chorological categories, Raunkiær life forms and CSR plant strategies. Landscape surrounding each field was assessed in four circular buffers of radii ranging from 250 to $1500 \mathrm{~m}$. Attributes characterising fields and field margins were also considered.

Community composition and diversity of weed communities were affected by field and landscape characteristics. Old and new abandonment increased species richness and weed diversity but had an opposite effect on the Raunkiær functional response groups. Urban sprawl was positively correlated with abundance of geophytes, competitive and cosmopolite species and negatively correlated with therophytes and competitive-ruderals. Most landscape parameters had stronger effect at the smallest scale. The effect of landscape parameters was clearer when weeds were classified by functional response trait than by taxonomy.
\end{abstract}

(c) 2013 Elsevier B.V. All rights reserved.

\section{Introduction}

Spontaneous vegetation in agroecosystems supports many agroecological services, e.g. harbouring pest predators, parasitoids and pollinators, reducing soil erosion and nitrogen leaching, and favouring nutrient retention (see also Marshall and Moonen, 2002). However, these services are counterbalanced by negative effects such as competition with crops, whose extent is largely determined by weed community composition and abundance within fields. The latter are known to be affected by local factors such as agricultural management (Kleijn and Verbeek, 2000), site habitat conditions (Duprè and Ehrlén, 2002), and agroecosystem history (Bruun and Fritzbøger, 2002). More recently, research is also focusing on the effect of landscape features (Roschewitz et al., 2005; Simmering et al., 2006; Gaba et al., 2010; José-María et al., 2010; Poggio et al., 2010, 2012). Presence and relative abundance of weed functional

\footnotetext{
* Corresponding author. Tel.: +39 050 883567; fax: +39 050883526.

E-mail addresses: s.carlesi@sssup.it (S. Carlesi), g.bocci@sssup.it (G. Bocci), moonen@sssup.it (A.-C. Moonen), p.frumento@sssup.it (P. Frumento), barberi@sssup.it (P. Bàrberi).
}

response groups have been used as a more effective way to explain the relationships between landscape structure and composition and weed community composition (Liira et al., 2008). Clarifying these relationships could help agricultural managers to find the right balance between control and preservation of weeds, and land planners to evaluate consequences of land use change on surrounding farmland.

Studies on the role of natural patches (Murphy and LovettDoust, 2004) or field margins (Kleijn and Verbeek, 2000; Marshall and Moonen, 2002; Marshall, 2004) on weed composition and/or diversity have mostly been conducted in intensively cultivated areas. Instead, areas characterised by agricultural land abandonment and urban sprawl have so far been neglected, although these are two important drivers of change in EU landscapes (Jongman, 1995; Verburg et al., 2006) and especially in the Mediterranean region (Schmitz et al., 2003).

The aim of this paper was to study the effects of landscape structure and composition on maize (Zea mays L.) weed communities in a highly anthropised Mediterranean coastal agricultural landscape characterised by different levels of abandonment and urbanisation. We hypothesised that land use change determines new landscape arrangements which affect weed community composition 
and diversity. According to the mosaic concept (Duelli, 1997) we expect land use heterogeneity enhance species richness creating more opportunity for different species to establish, grow and reproduce, spread and reach the cultivated fields. As far as species composition is concerned, we suppose that an increasing level of fragmentation will support the presence of those species that are more suitable to colonise interstitial - not tilledareas, as geophytes, through the mass effect (Shmida and Wilson, 1985). Similarly, we expect the increasing presence of obstacles (e.g. new buildings, fences, etc.), will lead to a lower presence of therophytes since those structures may decrease their capacity to move through the landscape, as noticed by Poggio et al. (2010).

We predict that the resulting changes in species composition are related to the species traits, and we therefore hypothesise that land use changes can be better understood using an approach based on weed functional response traits instead of taxonomy only, thus identifying groups of species with a similar response to land use dynamics. If the use of functional response trait will be strengthen, this would help making expected changes in weed community more comparable among regions.

\section{Methods}

\subsection{Site description}

The region has a Mediterranean climate and is located along the coastal plain of the bordering Provinces of Massa-Carrara (Northern Tuscany, Central Italy) and La Spezia (Eastern Liguria, Northern Italy), from $43^{\circ} 59^{\prime}$ to $44^{\circ} 07^{\prime}$ lat. $\mathrm{N}$ and from $9^{\circ} 55^{\prime}$ to $10^{\circ} 11^{\prime}$ long. E. We selected a study region of ca. $75 \mathrm{~km}^{2}$ where agriculture is still the prevailing land use type but where large areas are increasingly affected by urbanisation, fragmentation and agricultural land abandonment (Fig. 1). In this region we chose 21 maize fields, the main arable crop grown in the area (it covers $22.3 \%$ of total arable land in the two considered provinces (ISTAT, 2001)) in such a way that a wide range of landscape configurations were represented: from homogeneous agricultural to highly fragmented landscape affected by urban sprawl or land abandonment.

\subsection{Weed sampling}

In each field, weeds were sampled at three distances $(5,10$, and $15 \mathrm{~m}$ ) from the field margin (FM). At each distance three sampling points of $1 \mathrm{~m}^{2}$ quadrat were taken parallel to $\mathrm{FM}$ and at $5 \mathrm{~m}$ distance from each other. The farthest distance from the FM, $15 \mathrm{~m}$, is hereafter referred to as 'field centre'. Weed species within each quadrat were listed and ground cover by species was visually estimated, and used to calculate: species richness $(\mathrm{S})$ expressed as number of species per quadrat.

Weed species were taxonomically classified after (Pignatti, 1982) and subsequently classified in functional response groups based on three functional response traits: (1) chorological categories (Pignatti et al., 2005), (2) Raunkiær life forms (Pignatti et al., 2005) (3) CSR plant strategies (Grime, 1979; White et al., 1997; Klotz et al., 2002; Hodgson, 2010) as detailed in Appendix A. The three groups of functional response traits were selected because they provide information about species' response to environmental conditions and the potential damage they may cause to crops: chorological category gives information about adaptability to new environmental conditions and spreading ability, Raunkiær life forms, based on the position of perpetuating buds, gives insight into the predominant ecological condition as disturbance levels (in arable fields especially weeding techniques)
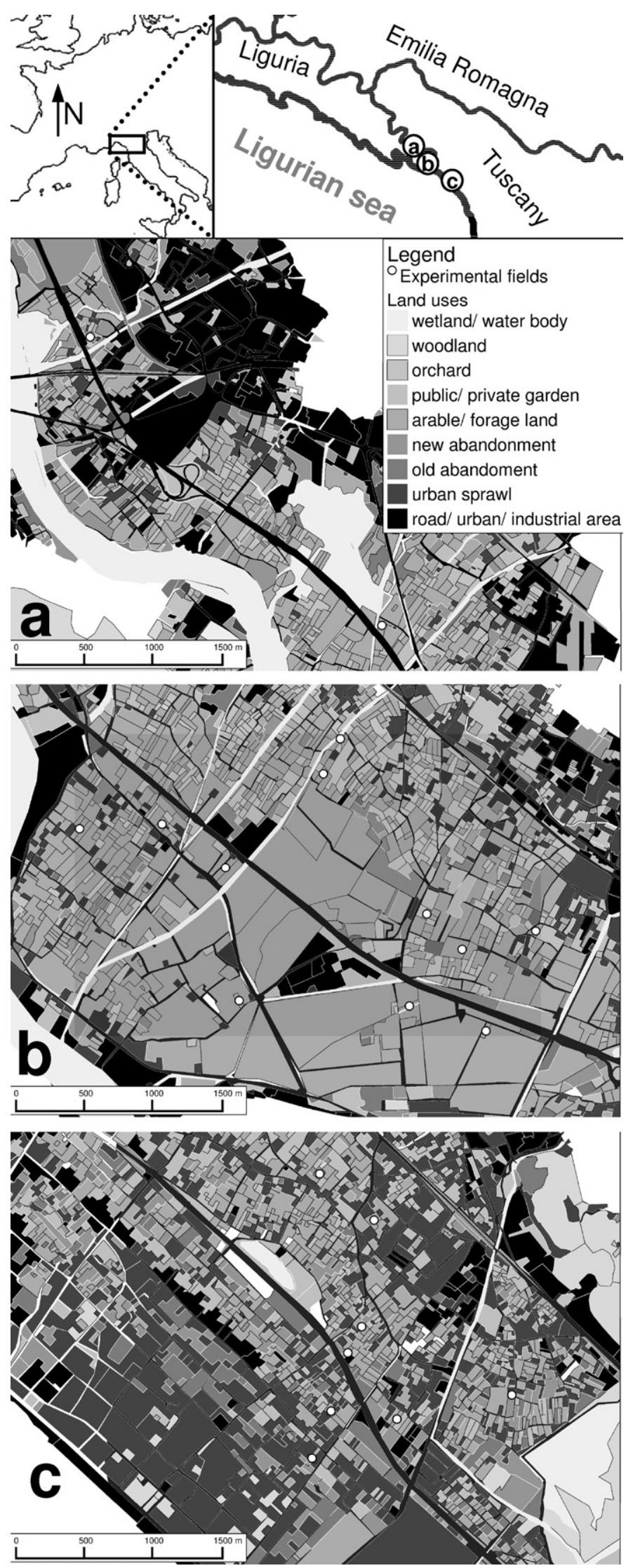

Fig. 1. Location and land use maps of the zone selected for the study in 2008. White dots represent sampled maize fields. Similar land uses have been aggregated to ease visual interpretation. Panels indicated by the letters "a","b", and "c" are located as reported in the upper left wider maps. 
Table 1

Parameters used for characterisation of field, field margins, landscape structure and landscape composition.

\begin{tabular}{|c|c|c|c|c|}
\hline Parameter group and name & Explanation/unit of measure & Formula & Range (min-max) & References \\
\hline \multicolumn{5}{|l|}{ 1. Field } \\
\hline 1.1 Nitrogen rate & Applied to maize [ $\left.\mathrm{kg} \mathrm{N} \mathrm{ha}^{-1}\right]$ & - & $60-350$ & - \\
\hline 1.2 Weed management & $\begin{array}{l}\text { Mechanical, chemical, } \\
\text { mechanical + chemical }\end{array}$ & - & & - \\
\hline $\begin{array}{l}\text { 1.3 Crops other than maize } \\
\text { grown in the last five years }\end{array}$ & $\begin{array}{l}\text { Indicates cropping system } \\
\text { diversity }\end{array}$ & - & $1-4$ & - \\
\hline 1.4 Tillage depth & {$[\mathrm{cm}]$} & - & $25-50$ & - \\
\hline 1.5 Maize seeding rate & [No. seeds $\left.\mathrm{m}^{-2}\right]$ & - & $7.4-11.1$ & - \\
\hline 1.6 Area & {$\left[\mathrm{m}^{2}\right]$} & - & $1324-9153$ & - \\
\hline 1.7 Perimeter length & {$[\mathrm{m}]$} & - & $153-531$ & - \\
\hline 1.8 Perimeter/area ratio & {$\left[\mathrm{m} \mathrm{m}^{-2}\right]$} & - & $0.045-0.1295$ & - \\
\hline 2. Field margins & 3 or 4 for each field & & & \\
\hline 2.1 Mean width & {$[\mathrm{m}]$} & - & $0.4-8$ & - \\
\hline 2.2. Management & $\begin{array}{l}\text { Mowing, cutting, chemical } \\
\text { weeding, none }\end{array}$ & - & & - \\
\hline $\begin{array}{l}\text { 2.3 Shannon diversity index } \\
\text { of vegetation }^{\mathrm{a}}\left(H^{\prime}\right)\end{array}$ & Adimensional & $\begin{array}{l}H^{\prime}=\sum_{i=1, n} p_{i} \times \ln \left(p_{i}\right), \text { where } p_{i} \text { is the percent } \\
\text { cover of species } \mathrm{i} \text {, and } \mathrm{n} \text { is the number of } \\
\text { species in the sampling area }\end{array}$ & $0-3.2$ & $\begin{array}{l}\text { Shannon and } \\
\text { Weaver (1949) }\end{array}$ \\
\hline $\begin{array}{l}\text { 2.4 Pielou evenness of } \\
\text { vegetation }^{\mathrm{a}}(\mathrm{J})\end{array}$ & $\begin{array}{l}\text { Indicates vegetation } \\
\text { equitability, adimensional }\end{array}$ & $\begin{array}{l}J=H^{\prime} / \log S \text { where } H^{\prime} \text { is the Shannon diversity } \\
\text { index of vegetation, and } S \text { is the number of } \\
\text { species in the sampling area }\end{array}$ & $0-0.94$ & Sheldon (1969) \\
\hline 2.5 Weediness of vegetation ${ }^{\mathrm{a}}$ & $\begin{array}{l}\text { Indicates weed species cover } \\
\text { in the field margin (\%). }\end{array}$ & $\begin{array}{l}\text { Weed species cover/total plant species cover } \\
\text { 'Weeds' are those species with cover }>1.5 \% \text { in } \\
\text { overall field transects. See Appendix C }\end{array}$ & $0-100$ & $\begin{array}{l}\text { Moonen et al. } \\
(2006)\end{array}$ \\
\hline 3. Landscape structure (LS) & $\begin{array}{l}\text { At } 250,500,1000 \text { and } \\
1500 \mathrm{~m} \text { from field centroid. }\end{array}$ & & & \\
\hline 3.1 Mean patch size (MPS) & [ha] & - & $0.2-1.5$ & \\
\hline $\begin{array}{l}\text { 3.2 Standard deviation of } \\
\text { mean patch size }\end{array}$ & $\begin{array}{l}\text { Indicates patch size } \\
\text { dissimilarity/heterogeneity }\end{array}$ & $\begin{array}{l}\text { sd (MPS) }=\left[\Sigma_{i=1, N}\left(x_{i}-x\right)^{2} / \mathrm{N}\right]^{1 / 2} \text {, where } x_{i} \text { is the } \\
\text { size of patch } i, x \text { is the mean size of all patches, } \\
\text { and } N \text { is the number of patches }\end{array}$ & $0.3-6.9$ & $\begin{array}{l}\text { Baker and Cai } \\
(1992)\end{array}$ \\
\hline 3.3 Total density & Number & Total No. of patches in a given buffer & $16-1582$ & $\begin{array}{l}\text { Baker and Cai } \\
(1992)\end{array}$ \\
\hline 3.4 Patch shape index (PSI) & Indicates patch shape & PSI $=(0.282 \times$ perimeter $) /(\text { area })^{1 / 2}$ & $\begin{array}{l}1.8 \text { (roundish)-2.4 } \\
\text { (stretched) }\end{array}$ & $\begin{array}{l}\text { Austin (1984), } \\
\text { MacEachren (1985) }\end{array}$ \\
\hline $\begin{array}{l}\text { 3.5 Standard deviation of } \\
\text { Patch Shape Index }\end{array}$ & $\begin{array}{l}\text { Indicates field shape } \\
\text { dissimilarity/heterogeneity }\end{array}$ & $\begin{array}{l}\text { sd }(\mathrm{PSI})=\left(\Sigma_{i=1, N}\left(x_{i}-x\right)^{2} / N\right)^{1 / 2} \text { where } x_{i} \text { is the } \\
\text { Shape Index of patch } i, x \text { is the mean shape } \\
\text { index of all patches, and } N \text { is the number of } \\
\text { patches }\end{array}$ & $0.7-2.1$ & Baker \& Cai, 1992 \\
\hline 3.6 Land use richness & $\begin{array}{l}\text { Indicates habitat richness } \\
\text { (No.) }\end{array}$ & $\begin{array}{l}\text { Number of different land uses as indicated in } \\
4.1\end{array}$ & $5-14$ & Baker \& Cai, 1992 \\
\hline $\begin{array}{l}\text { 3.7 Shannon diversity index } \\
\text { of land use }\left(H^{\prime}\right)\end{array}$ & Indicates habitat diversity & $\begin{array}{l}H^{\prime}=\sum_{\mathrm{i}=1, n} p_{i} \times \ln \left(p_{i}\right) \text { where } \mathrm{p}_{\mathrm{i}} \text { is the fraction of } \\
\text { the zone occupied by attribute } \mathrm{i} \text {, and } \mathrm{n} \text { is the } \\
\text { number of attributes in the zone }\end{array}$ & $0.8-2.5$ & Peet (1974) \\
\hline $\begin{array}{l}\text { 3.8 Dominance index of land } \\
\text { use (D) }\end{array}$ & $\begin{array}{l}\text { Indicates habitat } \\
\text { homogeneity }\end{array}$ & $\begin{array}{l}D=\ln _{(n)}-H^{\prime} \text {, where } n \text { is the number of } \\
\text { attributes in the zone }\end{array}$ & $0.13-1.0$ & O'Neill et al. (1988) \\
\hline $\begin{array}{l}\text { 3.9 LUIS (Land Use Inverse } \\
\text { Simpson index) }\end{array}$ & Indicates habitat diversity & $\begin{array}{l}1 / S=1 / \Sigma_{i=1, m} p_{i}{ }^{2} \text {, where } p_{i} \text { is the fraction of the } \\
\text { sampling area occupied by attribute } i \text {, and } m \text { is } \\
\text { the total number of attributes within the } \\
\text { sampling area }\end{array}$ & $1.6-10.7$ & Peet (1974) \\
\hline $\begin{array}{l}\text { 4. Landscape composition } \\
\text { (LC) }\end{array}$ & $\begin{array}{l}\text { At } 250,500,1000 \text { and } \\
1500 \mathrm{~m} \text { from field centroid. }\end{array}$ & & & \\
\hline 4.1 Land use ratio & $\begin{array}{l}\text { Ratio of total land under each } \\
\text { of the land use categories } \\
\text { identified [\%] }\end{array}$ & $\begin{array}{l}\text { Land use categories: woodland, forage land } \\
\text { (grassland/pasture/meadow), industrial area, } \\
\text { new abandonment, old abandonment, orchard, } \\
\text { arable land, private garden, urban area, public } \\
\text { garden, urban sprawl, road, wetland and water } \\
\text { body }\end{array}$ & $0-100$ & - \\
\hline
\end{tabular}

a Sampled in field margin (see text for further explanation).

and the favourable growing season (Raunkiaer, 1934; Crawley, 2009), CSR plant strategies give information about reproductive strategy, resource needs and ability towards the disturbance regime.

The field margin was defined as the not tilled area between each maize field and the adjacent area (Marshall and Moonen, 2002). Weed percent cover by species in each field margin was visually estimated in one quadrat ( $1 \mathrm{~m}$ wide $\times 20 \mathrm{~m}$ along the FM). Subsequently, Shannon diversity index $\left(\mathrm{e}^{\wedge} \mathrm{H}^{\prime}\right)$, the number of equally common species in an assemblage (Magurran, 2004), Pielou evenness of vegetation (J) (Sheldon, 1969), and weediness of vegetation (Moonen et al., 2006) (Table 1) were calculated for field margin vegetation.

\subsection{Field, field margin and landscape characterisation}

A $75 \mathrm{~km}^{2}$ land use map was created through photointerpretation and validated by a survey carried out in 2008, during which crop management, FM structure and management parameters were collected by structured interviews and field observations. Aerial orthophotos (Terraltaly, 2007), Regional Technical Maps (CTR, 2001) and CORINE land cover based on 1988/1989 aerial photos (CLC, 1995) were used through QGIS 1.0.2 (Quantum GIS Development Team, 2009). Four groups of parameters were used to characterise (1) field (F), (2) field margins (FM), (3) landscape structure (LS), and (4) landscape composition (LC). The full list and description of the parameters is reported in Table 1. 
We classified areas as 'abandonment' when, according to CORINE, they were cultivated in 1988 but were re-colonised by shrubs (new abandonment) or by more advanced vegetation successional stages (old abandonment) in 2007 aerial photos and/or field surveys. We classified as 'urban sprawl' areas with presence of civil urbanisation in the $2007 / 2008$ aerial photos/survey but not classified as urban areas in the 1988/1989 maps.

Landscape structure and composition were analysed in different concentric buffers with various radii $(250,500,1000$ and $1500 \mathrm{~m})$ from each field centroid (the upper limit was set to $1500 \mathrm{~m}$ because four fields were closer than $1500 \mathrm{~m}$ to the coastline). Parameters of LS and LC were measured using the command r.le (Baker and Cai, 1992) in the GRASS GIS software (GRASS Development Team, 2007).

\subsection{Statistical analyses}

To the best of our knowledge generalised additive models (GAM) have never been used in works studying landscape descriptors effects on weed diversity and composition (Gabriel et al., 2005; Roschewitz et al., 2005; Marshall, 2009; Gaba et al., 2010; JoséMaría et al., 2010; Poggio et al., 2010). Since there is no theoretical knowledge which suggest to assume the relationship between the dependent and the independent variables to be either linear or monotonic, as described by Guisan et al. (2002), we suppose that a more flexible instrument, such as GAM (Hastie and Tibshirani, 1990), which does not rely on these assumption, could give a good explanation of the flora composition at landscape varying.

Another big issue in ecological studies is represented by the selection of the variables to consider in the model. In the above mentioned studies authors (Roschewitz et al., 2005; Marshall, 2009; Poggio et al., 2010) selected the variables to be tested a priori. Other authors (Gaba et al., 2010; José-María et al., 2010) since factors that affect flora composition can be influenced by a wide range of source variability (see also Guisan and Zimmermann, 2000) used an automatic stepwise selection. We opted for an integration of the two approaches selecting only those meaningful independent variables which were not correlated, thus maintaining complexity of the model reducing the number of factors according to the degree of freedom.

Among the full list of parameters (Table 1) a first screening showed parameters with high $\left(R^{2}>0.43\right)$ and significant $(P<0.01)$ correlation with other parameters of the same group (e.g. buffer $1000 \mathrm{~m}$ see Appendix B). Those were excluded from subsequent analysis to reduce redundancy and limit the number of studied variables to the most relevant ones.

Subsequently data were analysed upon a sequence (Fig. 2) including (a) co-variable selection, (b) quantification and (c) qualification of parameters contribution to the explanation of weed community composition and diversity.

\subsubsection{Co-variable selection}

Among the field parameters considered (Table 1) a selection was made using cluster analysis based on field management Euclidean distances and K-means algorithm (MacQueen, 1967). Analysis of variance was used to test which field parameters were significantly explained $(P<0.05)$ by clustering. Two parameters describing field management were retained in subsequent analyses.

For each weed functional response group the FM parameter showing the higher linear correlation was retained for subsequent analysis.

Regression analyses were performed using LS and LC parameters reported in Table 1 as the explanatory variables and weed functional group as the dependent variable. These analyses were run for each buffer, giving a total of 1196 analyses [( 9 LS variables + 14 LC variables $) \times 4$ radii $\times 13$ functional response groups]. For each combination of LS or LC variable and functional response group we then plotted the resulting $R^{2}$ against the buffer radius and selected the buffer expressing the highest $R^{2}$ if regression was coherent as proposed in Carlesi et al. (2010).

\subsubsection{Quantifying parameters contribution to explanation of weed community composition}

To measure how explanatory variables affected weed community composition and how distance from the FM modulated effects, we divided weed data into three groups based on distance from the FM $(5,10,15 \mathrm{~m})$ and for each group we built a dissimilarity matrix using the Jaccard dissimilarity index (Jaccard, 1912) based on species presence. Each matrix was then used in a permutational multivariate analysis of variance with an $F$-test based on the sequential sum of squares from raw data permutations as proposed by José-María et al. (2010). For field management and field margin we chose the parameters which resulted as the most significant ones from co-variable selection, while the two LS and the two LC parameters were chosen a priori considering the focus of the paper (Table 2). Four analyses were performed, one for each buffer. Since different buffers gave similar results, the $1000 \mathrm{~m}$ one was chosen to ease comparability with published work (José-María et al., 2010; Poggio et al., 2010). Analyses were run with the Adonis command provided by Vegan packages (Oksanen et al., 2009) for $R$ (R Development Core Team, 2011).

\subsubsection{Qualifying parameters contribution to explanation of weed diversity and community composition through functional response groups.}

Generalised additive models (GAM) were used to analyse how functional response groups and diversity of weed communities were influenced by a suitable group of explanatory variables. GAM are flexible tools which suffer loss of precision when complexity grows, in particular with co-variable collinearity. A parsimony approach was then adopted and a compromise between complexity and precision was found by using a model with five co-variables. Four of them were selected as indicated in the Preliminary covariable selection' paragraph: two variables, one continuous and one discrete related to the field (respectively nitrogen rate and weed management), one continuous variable related to FM characteristics (FM Shannon diversity index or FM weediness, see values distribution in Fig. 3, according to the covariable selection procedure), one continuous variable related to the landscape and one discrete variable for FM distance (Fig. 2). GAM allow to preserve an additive structure, as in traditional linear models. A smoother was used to obtain nonparametric estimates of the relationship between the outcome (species richness or functional groups relative) and the continuous explanatory variables. Sum of squares and significance level were considered for each combination, the most representative of which was then refined, modifying the degree of smoothing of each continuous covariate. The LS or LC effects on the dependent variable (species richness or functional groups) were shown as schematised curves respectively in Tables 3 and 4. The group of 4 covariable selected for each group of dependent variable used in the model together with LS or LC, and the relative significance, were reported in Table 5.

Analyses were performed using GAM packages for R (Hastie and Tibshirani, 1990; Chambers and Hastie, 1991). GAM objects shape are represented as proposed by Bischoff et al., 2005.

\section{Results}

\subsection{Weed community diversity and composition}

We recorded 61 weed species in the 21 fields (Appendix A) and 145 in the field margins (Appendix C). 


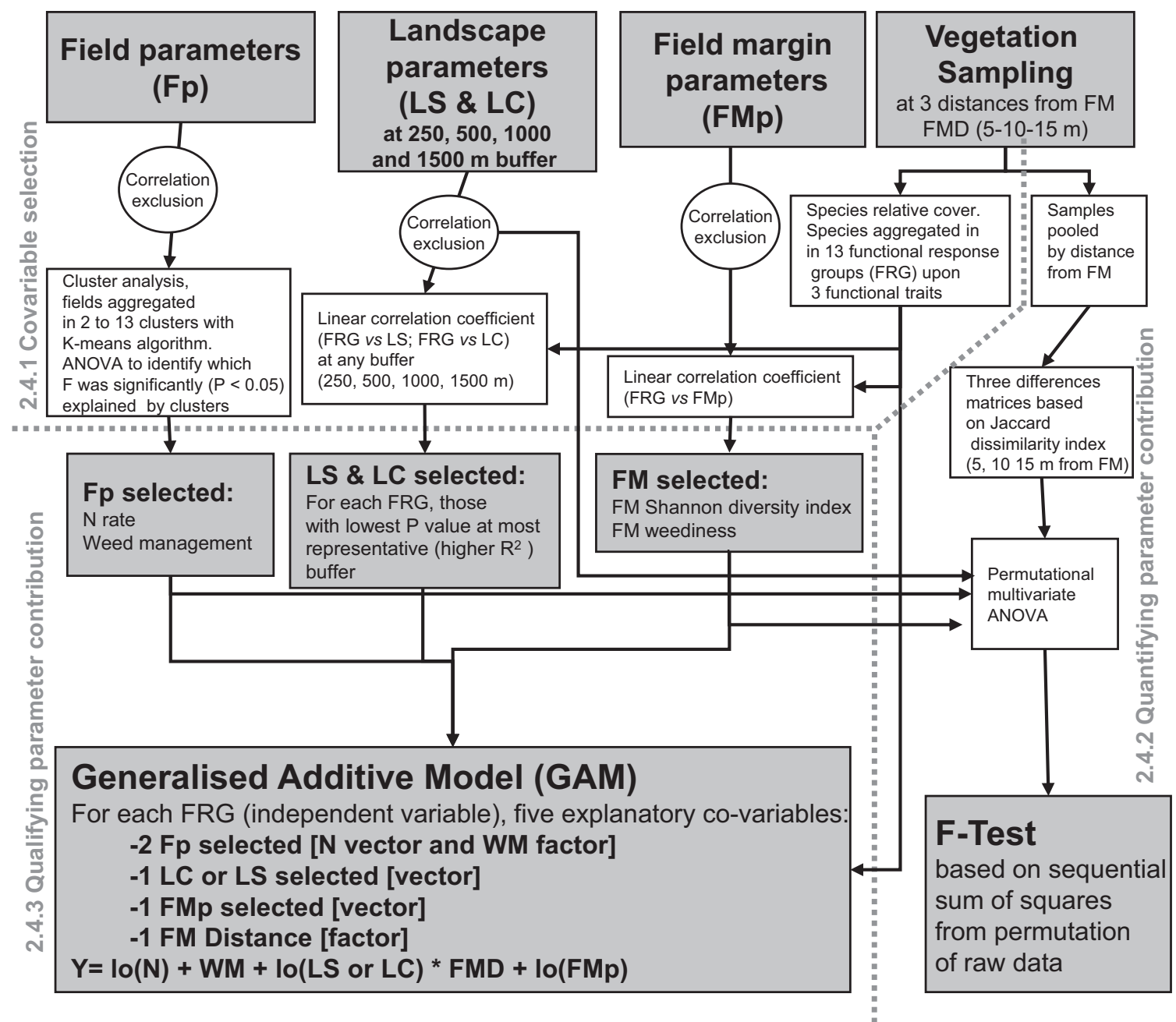

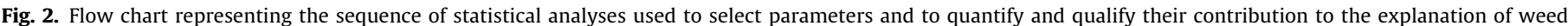

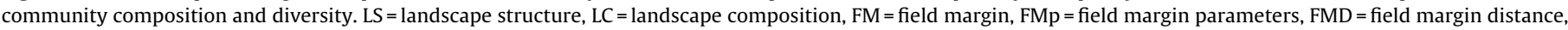


correlation with other parameters of the same group were excluded.

The species richness (S) (see values distribution in Fig. 3) was influenced by both LS and LC (Table 3 ) and was positively influenced by the presence of roads and new abandonment in a $250 \mathrm{~m}$ buffer and by high diversity in land use types in a $1500 \mathrm{~m}$ buffer. It was negatively correlated with PSI, thus in-field weed diversity decreased when fields were surrounded by patches with more elongated shape (Table 3).

Results from permutational multivariate analysis of variance (Table 2) showed that the effect of $\mathrm{N}$ rate (see values distribution in Fig. 3) on the weed community composition became stronger moving from the FM to the field centre, contrary to that of FM

Table 2

Results from permutational analysis of variance of community composition (Jaccard dissimilarity index; d.f. =77).

\begin{tabular}{|c|c|c|c|c|c|c|c|c|c|c|c|c|}
\hline \multirow[t]{3}{*}{ Explanatory variable } & \multicolumn{12}{|c|}{ Distance from the field margin } \\
\hline & \multicolumn{4}{|l|}{$5 \mathrm{~m}$} & \multicolumn{4}{|l|}{$10 \mathrm{~m}$} & \multicolumn{4}{|l|}{$15 \mathrm{~m}$} \\
\hline & SS & $r^{2}$ & $P$ & & SS & $r^{2}$ & $P$ & & SS & $r^{2}$ & $P$ & \\
\hline $\mathrm{N}$ & 0.475 & 0.014 & 0.215 & NS & 0.727 & 0.021 & 0.014 & $*$ & 1.023 & 0.030 & 0.002 & $* *$ \\
\hline FMW & 0.740 & 0.021 & 0.005 & $* *$ & 0.570 & 0.017 & 0.084 & $\bullet$ & 0.492 & 0.015 & 0.188 & NS \\
\hline NewAb & 1.538 & 0.044 & 0.001 & $* * *$ & 1.101 & 0.032 & 0.001 & $* *$ & 0.934 & 0.027 & 0.003 & $* *$ \\
\hline OldAb & 1.087 & 0.031 & 0.001 & $* * *$ & 0.842 & 0.025 & 0.005 & $* *$ & 1.003 & 0.029 & 0.003 & $* *$ \\
\hline PSI & 0.608 & 0.018 & 0.048 & $*$ & 0.405 & 0.012 & 0.461 & & 0.332 & 0.010 & 0.076 & \\
\hline MPS & 0.0970 & 0.028 & 0.001 & $* * *$ & 1.438 & 0.042 & 0.001 & $* * *$ & 1.468 & 0.043 & 0.001 & $* * *$ \\
\hline Total & 34.642 & 1.000 & & & 34.229 & 1.000 & & & 34.066 & 1.000 & & \\
\hline
\end{tabular}

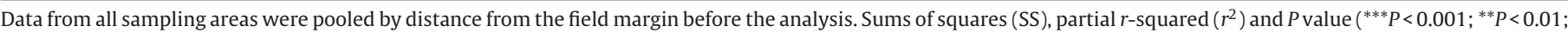

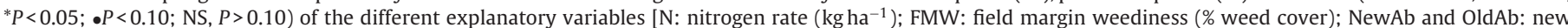

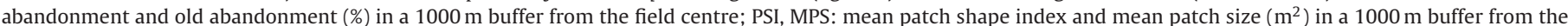
field centre] based on 999 permutations. 

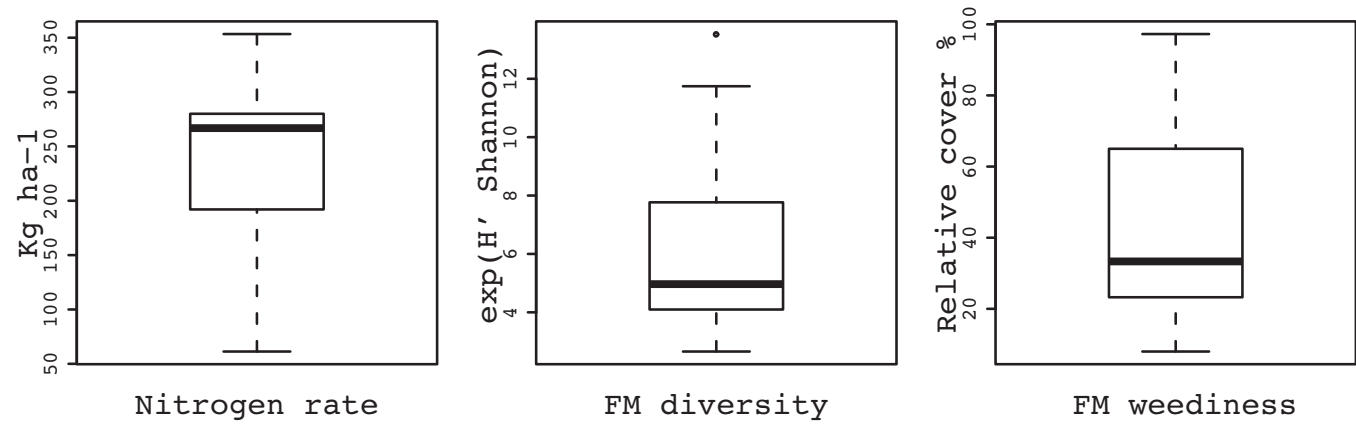

FM diversity

FM weediness
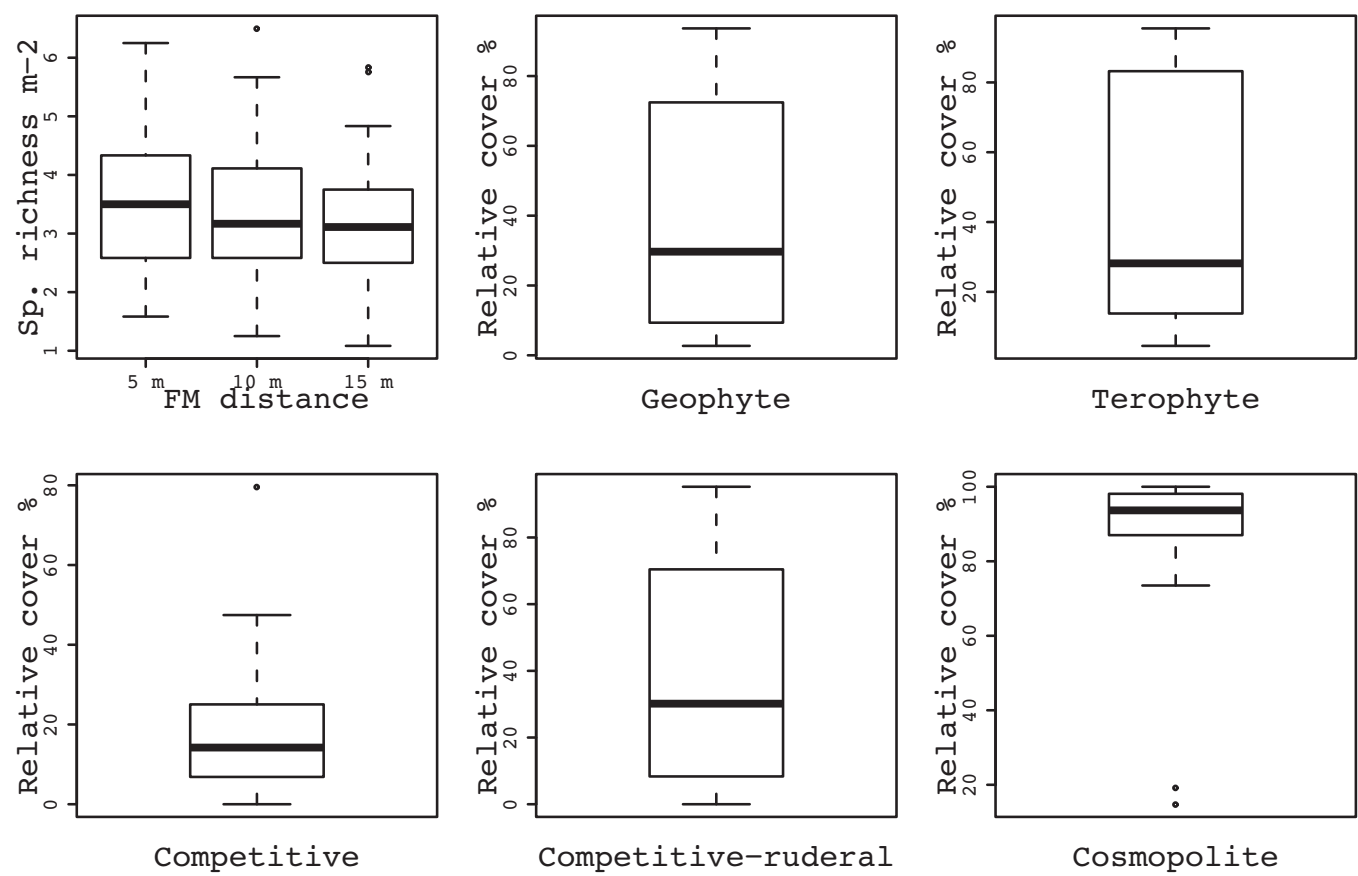

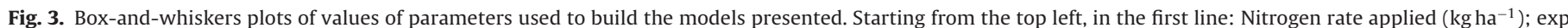

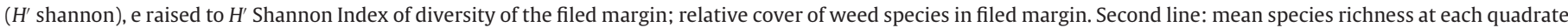

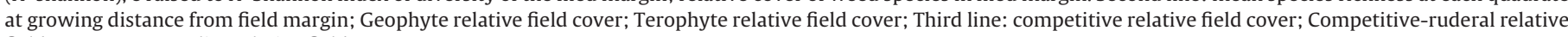
field cover; Cosmopolite relative field cover.

weediness. The effect of LS and LC parameters was homogeneous across transects for old abandonment, decreased from FM to the field centre for new abandonment and patch shape index (PSI), and it was stronger in the field centre for mean patch size (MPS).

\subsection{Weed functional response groups}

Among all the 13 functional response groups analysed, only the five whose frequency was $>50 \%$ across all sampling points are shown in Tables 4 and 5 and their values distribution in
Fig. 3. The presence of urban sprawl in a given buffer was the most important covariate affecting the abundance of all five functional response groups except for cosmopolite species. The type of relationship (graphical trend) differed among groups (Table 4): competitive, cosmopolite and geophytes species' relative presence increased, at increasing levels of urban sprawl while therophytes and competitive-ruderals decreased.

Geophytes and therophytes were the most abundant life forms (overall mean cover $=16.6 \%$ and $16.1 \%$ respectively) and were both highly sensitive to LC. Geophytes relative cover was positively

Table 3

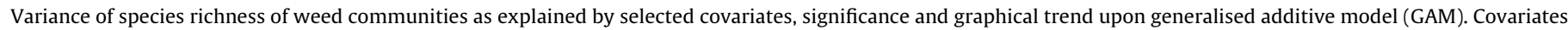
trends are reported at the buffer in which they had the highest explanatory power (lower $P$ value).

\begin{tabular}{|c|c|c|c|c|c|c|}
\hline Parameter & Covariate & Unit of measure & Buffer radius (m) & Variance explained (\%) & Sig. & Graphical trend \\
\hline \multirow[t]{4}{*}{$S$} & PSI & Adimensional & 250 & 8.9 & $* * *$ & $\backslash$ \\
\hline & LUIS & Adimensional & 1500 & 6.6 & $* * *$ & J \\
\hline & Road & $\%$ & 250 & 4.6 & $* * *$ & $\Gamma$ \\
\hline & NewAb & $\%$ & 250 & 4.0 & $* * *$ & 1 \\
\hline
\end{tabular}

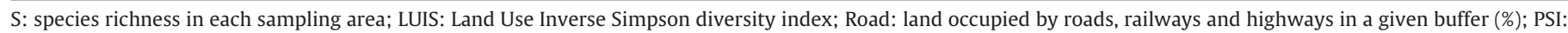

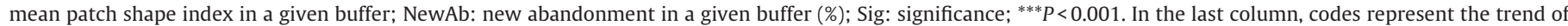

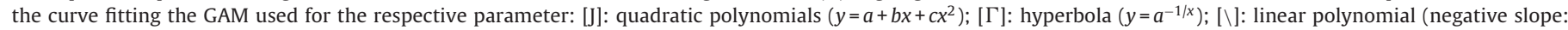
$y=a-b x$ ); [/]: linear polynomial (positive slope: $y=a+b x$ ); Curves parameters $(a, b, c)$ are assumed as positive. 
Table 4

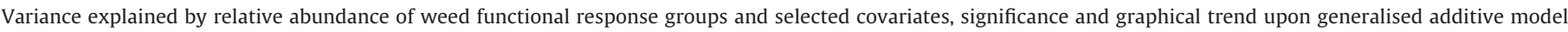
(GAM). Covariates trends are reported at the buffer in which they had the highest explanatory power (lower $P$ value).

\begin{tabular}{|c|c|c|c|c|c|c|c|}
\hline $\begin{array}{l}\text { Functional } \\
\text { response trait }\end{array}$ & $\begin{array}{l}\text { Functional } \\
\text { response group }\end{array}$ & Covariate & $\begin{array}{l}\text { Unit of } \\
\text { measure }\end{array}$ & $\begin{array}{l}\text { Buffer radius } \\
(\mathrm{m})\end{array}$ & $\begin{array}{l}\text { Variance } \\
\text { explained (\%) }\end{array}$ & Sig & $\begin{array}{l}\text { Graphical } \\
\text { trend }\end{array}$ \\
\hline \multirow[t]{7}{*}{ Raunkiær life form } & \multirow[t]{6}{*}{ Geophyte } & Sprw & $\%$ & 250 & 18.7 & $* * *$ & 1 \\
\hline & & LUR & No. & 250 & 2.9 & $* * *$ & 1 \\
\hline & & NewAb & $\%$ & 250 & 2.1 & $* * *$ & 7 \\
\hline & & Sprw & $\%$ & 1500 & 8.0 & $* * *$ & 1 \\
\hline & & LUR & No. & 250 & 6.3 & $* * *$ & $i$ \\
\hline & & OldAb & $\%$ & 1000 & 6.1 & $* * *$ & 7 \\
\hline & Therophyte & PSI & Adimensional & 250 & 4.8 & $* * *$ & $\cap$ \\
\hline \multirow{9}{*}{ Grime strategy } & \multirow[t]{4}{*}{ Competitive } & Sprw & $\%$ & 1500 & 11.0 & $* * *$ & 1 \\
\hline & & OldAb & $\%$ & 1000 & 8.9 & $* * *$ & $\mathrm{~J}$ \\
\hline & & MPS & $\mathrm{m}^{2}$ & 500 & 7.3 & $* * *$ & 7 \\
\hline & & LUR & No. & 250 & 5.78 & $* * *$ & $\Gamma$ \\
\hline & \multirow[t]{5}{*}{ Competitive-ruderal } & Sprw & $\%$ & 250 & 11.9 & $* * *$ & 1 \\
\hline & & NewAb & $\%$ & 250 & 11.5 & $* * *$ & i \\
\hline & & PSI & Adimensional & 250 & 8.7 & $* * *$ & 7 \\
\hline & & MPS & $\mathrm{m}^{2}$ & 500 & 7.1 & $* * *$ & $\mathrm{~J}$ \\
\hline & & Road & $\%$ & 500 & 3.3 & $* * *$ & $\mathrm{~J}$ \\
\hline \multirow[t]{5}{*}{ Chorological category } & \multirow[t]{5}{*}{ Cosmopolite } & LUR & No. & 250 & 8.0 & $* * *$ & 1 \\
\hline & & MPS & $\mathrm{m}^{2}$ & 250 & 4.6 & $* * *$ & i \\
\hline & & Sprw & $\%$ & 1500 & 4.4 & $* * *$ & 1 \\
\hline & & PSI & Adimensional & 250 & 2.2 & $* * *$ & $\mathrm{Z}$ \\
\hline & & NewAb & $\%$ & 1000 & 1.8 & $* *$ & $\mathrm{~S}$ \\
\hline
\end{tabular}

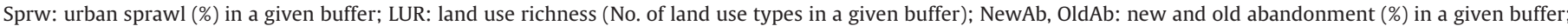

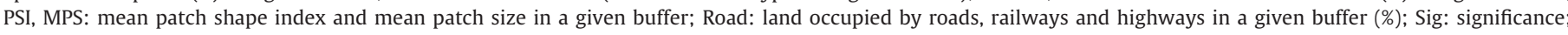

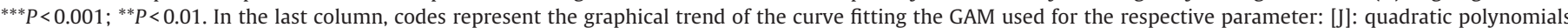

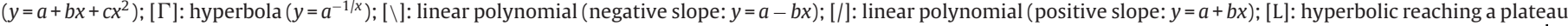

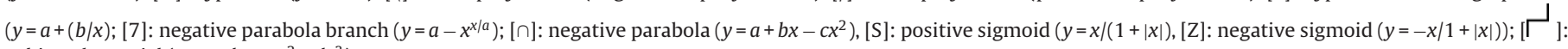
cubic polynomial $\left(y=a+b x+c x^{2}+d x^{3}\right)$.

correlated with land use richness in a $250 \mathrm{~m}$ buffer and negatively correlated with new abandonment (Table 4). Therophytes were more abundant at intermediate values of PSI (1.9-2.0).

Among CSR strategie groups, competitive species were the most abundant (overall mean cover $=20.4 \%$ ), followed by competitiveruderals (15.7\%). Competitives were positively influenced by urban sprawl and old abandonment, but responded significantly also to MPS in a $500 \mathrm{~m}$ buffer and land use richness in a $250 \mathrm{~m}$ buffer (linear positive relationship with an intermediate plateau) (Table 4). Competitive-ruderals were positively influenced by presence of new abandonment and by increasing MPS, while they were negatively influenced by PSI but only at high values.

Cosmopolites weed cover diminished with increasing land use richness, while it increased with mean patch size and urban sprawl presence (Table 4).

\section{Discussion}

Studying the effect of abandonment and urbanisation of the surrounding landscape on maize fields weed communities, we verified that beside the "classical" local-scale determinants, factors acting at a wide landscape scale played a consistent role in affecting weed communities diversity and composition. Furthermore species classification using functional response traits enabled us to connect the differencies in communities composition with the landscape mechanisms that drive them.

\subsection{Effect of field parameters on weed community}

Nitrogen rate and weed management were the main crop management filters of weed community composition since they influenced significantly all weed parameters and functional response groups (Table 2 ). $\mathrm{N}$ rate affected more the weeds in the field centre than those closer to field margin and reduced weed diversity, in accordance with Kleijn et al. (2009) and José-María et al. (2010).

As shown by partial $R^{2}$ values in Table 2 , at least one landscape parameter had a stronger effect than field parameters at each distance from the field margin. Gaba et al. (2010), José-María et al. (2010) and Marshall (2009), did not find any effect of landscape

Table 5

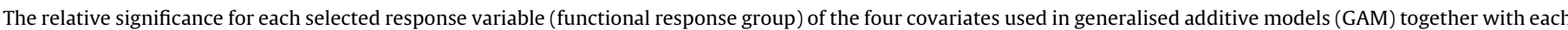
LS and LC reported in Tables 3 and 5 and of the interaction among LS or LC reported in Tables 3 and 5 and distance form FM.

\begin{tabular}{|c|c|c|c|c|c|c|}
\hline \multirow[t]{2}{*}{ Response variable/functional group } & \multicolumn{5}{|l|}{ Covariate } & \multirow{2}{*}{$\begin{array}{l}\text { Interaction } \\
\text { (LS/LC):Dist }\end{array}$} \\
\hline & $N$ rate $\left(\mathrm{kg} \mathrm{ha}^{-1}\right)$ & $\mathrm{e}^{H^{\prime}}(\mathrm{FM})$ & FMW & Dist & NM & \\
\hline Species richness & $* * *$ & $\bullet$ & - & NS & $* * *$ & NS \\
\hline Geophyte & $*$ & - & $* * *$ & NS & $* * *$ & NS \\
\hline Terophyte & $* * *$ & - & $* * *$ & NS & $* * *$ & NS \\
\hline Competitive & $* * *$ & - & $* * *$ & NS & $* * *$ & NS \\
\hline Competitive-ruderal & $*$ & - & $* * *$ & NS & $* * *$ & NS \\
\hline Cosmopolite & $*$ & - & $* * *$ & NS & $* * *$ & NS \\
\hline
\end{tabular}

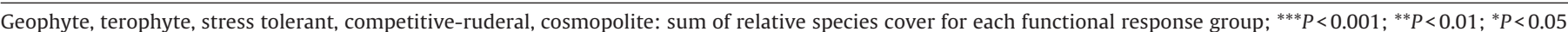

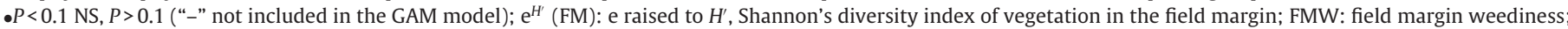
Dist: sample distance from the field margin; WM: weed management; (LS/LC):Dist interaction among Landscape parameters and distance from FM. 
parameters on weed community composition in the field centre, an effect they explained with the strong filtering effect of crop management intensity. In our case, mean field size $\left(5700 \mathrm{~m}^{2}\right)$ was smaller than theirs and crop management resulted less intensive. Consequently we find that the strongest explanatory variable for weed composition, even at field centre ( $15 \mathrm{~m}$ distance from the field edge) was a landscape one (mean patch size).

\subsection{Effect of field margin parameters on weed community}

Distance from field margin seemed an important factor when weed community composition was analysed with a taxonomic approach (Table 2) but not with a functional response group approach (Table 5). Parameters of field margin vegetation, $\mathrm{e}^{H^{\prime}}$ and weediness, influenced in-field abundance of weed functional response groups significantly but independent of distance (Table 5). Conversely the effect of field margin weediness decreased from the margin to the field centre, on weed community composition within fields (Table 2), indicating that the species that have the ability to spread from margin had a limited moving or survival capacity as reported by Marshall (1989).

\subsection{Effect of landscape structure and composition on weed diversity within fields}

Land Use Inverse Simpson Index (Table 3), shows that increasing level of diversity and heterogeneity of land use increase the species richness within fields, in accordance with mosaic concept (Duelli, 1997), which suggests that patch species richness is a function of habitat variability and heterogeneity of the surrounding landscape, and other field studies (Liira et al., 2008; Gaba et al., 2010; Poggio et al., 2010).

On the contrary decreasing of Patch shape index (more roundish patches) tended to be correlated with higher weed diversity (Table 3). Since the increase of patch shape index (more elongated patches) is positively correlated with urban sprawl and negatively with arable land presence $(r>0.55)$, the main cause of diversity decrease can be ascribed to effects of fragmentation (patch shape index). Therefore our findings slightly differ from what was found by other researchers (Gaba et al., 2010; Poggio et al., 2010). We suppose that in a more fragmented landscape typical maize weeds, like competitive-ruderals and therophytes, find more barriers and have less suitable habitat at their disposal. Thus, even considering the crucial role that connectivity plays in Metapopulation hypothesis (Levins, 1969; Hanski, 1998), so we may state that patches that are smaller and more elongated in shape reduced connectivity and consequently diversity.

Anyway as underlined by Harrison and Bruna (1999) to distinguish effects of habitat loss from changes in spatial configuration is a basic issue in fragmentation studies which cannot be easy solved.

Intensively cultivated areas did not affect weed diversity and this could be explained by the fact that arable fields mainly host common species (Simmering et al., 2006) and therefore do not contribute to an increased species richness at landscape level. In contrast, semi-natural patches (new and old abandonment) increased species richness in cultivated field closer than $1500 \mathrm{~m}$ : considering Simmering et al. (2001) view of 'old fields' as hotspots of diversity, a mass effect (Roschewitz et al., 2005) can be hypothesised.

Presence of roads, calculated as percentage of landscape surface occupied by transport infrastructure, mainly roads, supported higher biodiversity, as also shown by Bratli et al. (2006), but competitive-ruderal species were its main component, confirming that road verges are suitable habitats for species tolerating human disturbance (Forman and Alexander, 1998) that can establish and survive also in arable fields.

\subsection{Effects of landscape structure and composition on weed community composition within fields}

The two types of abandonment gave completely opposite results on in-field weed community composition. New abandonment favoured species which mainly reproduce by seed and tolerate disturbance of the growth cycle, like competitive-ruderals, while old abandonment favoured vegetatively reproducing species with a low tolerance to disturbance as competitive species (Table 4). As hypothesised, different successional stages in seminatural patches resulted in different weed community composition across different spatial scales. We can assume that old abandoned fields in highly fragmented landscapes are potentially analogous to natural patches in large agricultural areas in continental scenarios where, according to Liira et al. (2008), natural habitat availability enhances perennial forbs richness. Both types of abandonment represent a threat to agricultural activities since they support different groups of species that contain extremely troublesome weeds in maize. Old abandonment may support Competitive and Geophyte species such as Cyperus esculentus, Elymus repens, Helianthus tuberosus and Sorghum halepense, whereas new abandoned supported Therophytes and Competitive-Ruderals such as Abutilon theophrasti, Amaranthus blitoides, Amaranthus retroflexus, Chenopodium album, Datura stramonium, Echinochloa crus-galli, Galinsoga parviflora, Polygonum lapathifolium, Polygonum persicaria, Setaria viridis, Solanum nigrum, Sonchus arvensis and Xanthium strumarium. The mass effects migration of troublesome species registered from new and old abandonment patches may suggest that regional species pool is limited by poor species availability, mainly characterised by weedy species.

Urban sprawl also significantly influenced weed community composition within fields: we found a positive correlation between cosmopolite relative abundance and urban sprawl that could be explained by the accidental or deliberate introduction of non native species as reported by Kowarik (2003). Urban sprawl had a contrasting effect on competitive and therophytes, supporting the former and decreasing the latter. This may be due to an indirect effect of urban sprawl, since it was positively associated with both old abandonment (in a $1500 \mathrm{~m}$ buffer, $P<0.005, r=0.62$ ) and more elongated patch shape index (in a $250 \mathrm{~m}$ buffer, $P<0.005$, $r=0.58$ ). All three parameters had a significant effect on weed community composition but it is hard to disentangle their single contribution.

Of all land use diversity indices used, land use richness was the one that better explained differences in weed functional response groups relative dominance, especially in a $250 \mathrm{~m}$ buffer. Our results suggest that habitat availability and landscape heterogeneity are the main landscape characteristics affecting field flora composition concurring with Gabriel et al. (2005) and Poggio et al. (2010), even if in the context considered landscape simplification favours cosmopolite, competitive-ruderals and therophytes whereas land use diversity favours competitive and geophytes, which in heterogeneous environments may find better opportunities for mass effect migration (Roschewitz et al., 2005).

Patch shape index and mean patch size had higher explanatory power at small scale buffers ( 250 and $500 \mathrm{~m}$ ). The effect of patch shape index on in-field weed community composition at landscape scale was mediated by the field margin. Among the species found close to the field margin but not in the field centre (see Section 3, weed community composition), the vast majority has a reduced capacity of propagule movement. Abundance of competitive-ruderals and cosmopolites was reduced by the presence of elongated and irregularly shaped patches, while it was favoured by larger patches. Our study revealed that high habitat fragmentation reduces diversity, but this is not necessarily 
negative since unfavoured species were mainly competitiveruderal and cosmopolite, of little or no value from an agroecosystem perspective because they include many typical agricultural weeds.

\subsection{Interplay between landscape parameters and spatial scale}

The highest variance explanation was found at a buffer of 250, 500,1000 and $1500 \mathrm{~m}$ for $15(60 \%), 3(120 \%), 3(12 \%)$ and $4(16 \%)$ of the 25 selected landscape covariables respectively. As such, our data support the findings of (Gaba et al., 2010), who indicated stronger effects of landscape parameters on weed community composition at a smaller scale. In contrast (Gabriel et al., 2005), who worked in a context of high agricultural intensification and landscape simplification, found stronger effects at larger buffers (ca. $1000 \mathrm{~m}$ ). We can then assume that the scale at which the effect of landscape parameters on weed community composition becomes clearer is context- and parameter-dependent. Furthermore, since some landscape parameters (e.g. urban sprawl or old abandonment) showed a higher effect at a larger scale, selecting just one landscape scale for all the analyses might increases the risk to miss out important relationship that exist between landscape and field.

\section{Conclusion}

In principle, both the taxonomic and functional approaches to the analysis of weed community composition are useful because they are complementary. However, our results show that a functional response trait approach can better highlight the effects of landscape features on weed community composition. Data indicate that drivers of weed community composition in highly anthropized landscapes, where urban sprawl and fragmentation are increasing while agricultural activities decreasing, should be studied with a slightly different methodological approach than in highly homogeneous landscapes, where intensive agriculture is the prevailing land use type (Gabriel et al., 2005; Roschewitz et al., 2005; Simmering et al., 2006; Sosnoskie et al., 2007; Liira et al., 2008; Kleijn et al., 2009; Gaba et al., 2010; José-María et al., 2010; Poggio et al., 2010) since in the former case the reduction of patches' dimensions or the presence of more elongated patches lead to a reduction of connectivity for keys groups of spontaneous species, while in the latter case the main effect was due to an increasing of patches heterogeneity, and than species diversity. Attention must be paid to the use of the same theoretical background for different group of species to explain existing processes, since the same landscape elements (e.g. linear ones) can provide completely different functions in two contrasting functional groups increasing the connectivity for geophytes and competitive or reducing connectivity for CR therophytes. Increase of urban sprawl, fragmentation and land abandonment is a general trend in many agricultural landscapes in Europe which are in a transformation process (Verburg et al., 2006) and this study demonstrated that these land use changes strongly affect weed dynamics in highly anthropized landscape. These changes are part of a trend that, if not reversed, would lead to a more competitive, less ruderal and less mobile weed species composition.

\section{Acknowledgements}

We thank Prof. Enrico Bonari, the Provincia di Massa Carrara (especially Stefano Bacci and Teresa Zattera), Ingolf Kühn and Ellen Selen, Coldiretti of Massa Carrara and all farmers involved (especially Mr. Francesco Della Pina). We also thank Maria John and Gaia Margheriti for their help.

\section{Appendix A. Supplementary data}

Supplementary data associated with this article can be found, in the online version, at http://dx.doi.org/10.1016/j.agee.2012.12.013.

\section{References}

Austin, R.F., 1984. Measuring and comparing two-dimensional shapes. In: Gaile, G.L., Willmontt, C.J. (Eds.), Spatial Statistics and Models. D. Reidel, Boston, MA, pp. 293-312.

Baker, W.L., Cai, Y., 1992. The r.le programs for multiscale analysis of landscape structure using the GRASS geographical information system. Landscape Ecol. 7, 291-302.

Bischoff, A., Auge, H., Mahn, E.-G., 2005. Seasonal changes in the relationship between plant species richness and community biomass in early succession. Basic Appl. Ecol. 6, 385-394.

Bratli, H., Økland, T., Økland, R.H., Dramstad, W.E., Elven, R., Engan, G., Fjellstad, W., Heegaard, E., Pedersen, O., Solstad, H., 2006. Patterns of variation in vascula plant species richness and composition in SE Norwegian agricultural landscapes. Agric. Ecosyst. Environ. 114, 270-286.

Bruun, H.H., Fritzbøger, B., 2002. The past impact of livestock husbandry on dispersal of plant seeds in the landscape of Denmark. Ambio 31, 425-431.

Carlesi, S., Bocci, G., Moonen, A.C., Frumento, P., Bàrberi, P., 2010. Maize weed communities composition in a highly anthropized landscape: which vegetation response variables and landscape descriptors? IOBC/Wprs Bulletin, 29-32.

Chambers, J., Hastie, T., 1991. Statistical Models in S. Wadsworth/Brooks Cole, Pacific Grove.

CLC, 1995. Corine Land Cover. EEA, Copenhagen, p. Regione Toscana.

Crawley, M.J., 2009. The Structure of Plant Communities. Plant Ecology. Blackwell Publishing Ltd., Oxford, pp. 475-531.

CTR, 2001. Cartografia Tecnica Regionale. Regione Toscana, Firenze.

Duelli, P., 1997. Biodiversity evaluation in agricultural landscapes: an approach at two different scales. Agric. Ecosyst. Environ. 62, 81-91.

Duprè, C., Ehrlén, J., 2002. Habitat configuration, species traits and plant distributions. J. Ecol. 90, 796-805.

Forman, R.T.T., Alexander, L.E., 1998. Roads and their major ecological effects. Annu. Rev. Ecol. Evol. Syst. 29, 207-231.

Gaba, S., Chauvel, B., Dessaint, F., Bretagnolle, V., Petit, S., 2010. Weed species richness in winter wheat increases with landscape heterogeneity. Agric. Ecosyst. Environ. 138, 318-323.

Gabriel, D., Thies, C., Tscharntke, T., 2005. Local diversity of arable weeds increases with landscape complexity. Perspect. Plant Ecol. Evol. Syst. 7, 85-93.

GRASS Development Team, 2007. Geographic Resources Analysis Support System (GRASS), http://grass.osgeo.org. Open Source Geospatial Foundation Project.

Grime, J.P., 1979. Plant Strategies and Vegetation Processes. John Wiley \& Sons, Chichester/New York/Brisbane/Toronto.

Guisan, A., Edwards Jr.F T.C., Hastie, T., 2002. Generalized linear and generalized additive models in studies of species distributions: setting the scene. Ecol. Model. 157, 89-100.

Guisan, A., Zimmermann, N.E., 2000. Predictive habitat distribution models in ecology. Ecol. Model. 135, 147-186.

Hanski, I., 1998. Metapopulation dynamics. Nature 396, 41-49.

Harrison, S., Bruna, E., 1999. Habitat fragmentation and large-scale conservation: what do we know for sure? Ecography 22, 225-232.

Hastie, T., Tibshirani, R., 1990. Generalized Additive Models. Chapman and Hall, London.

Hodgson, J.G., 2010. Allocating C-S-R types to plant species.

ISTAT, 2001. $5^{\circ}$ Censimento generale dell'Agricoltura.

Jaccard, P., 1912. The distribution of the flora in the alpine zone. New Phytol., 37-50.

Jongman, R.H.G., 1995. Nature conservation planning in Europe: developing ecological networks. Landscape Urban Plan. 32, 169-183.

José-María, L., Armengot, L., Blanco-Moreno, J.M., Bassa, M., Sans, F.X., 2010. Effects of agricultural intensification on plant diversity in Mediterranean dryland cereal fields. J. Appl. Ecol. 47, 832-840.

Kleijn, D., Kohler, F., Bàldi, A., Batàry, P., Concepciòn, E.D., Clough, Y., Diaz, M., Gabriel, D., Holzschuh, A., Knop, E., Kovàcs, A., Marshall, E.J.P., Tscharntke, T., Verhulst, J. 2009. On the relationship between farmland biodiversity and land-use intensity in Europe. Proc. R. Soc. B: Biol. Sci. 276, 903-909.

Kleijn, D., Verbeek, M., 2000. Factors affecting the species composition of arable field boundary vegetation. J. Appl. Ecol. 37, 256-266.

Klotz, S., Kühn, I., Durka, W., 2002. BIOLFLOR - Eine Datenbank mit biologischökologischen Merkmalen zur Flora von Deutschland. Schriftenreihe für Vegetationskunde, 197-201.

Kowarik, I., 2003. Human agency in biological invasions: secondary releases foster naturalisation and population expansion of alien plant species. Biol. Invasions $5,293-312$

Levins, R., 1969. Some demographic and genetic consequences of environmental heterogeneity for biological control. Bull. Ecol. Soc. Am. 15, 237-240.

Liira, J., Schmidt, T., Aavik, T., Arens, P., Augenstein, I., Bailey, D., Billeter, R., Bukáček R., Burel, F., De Blust, G., De Cock, R., Dirksen, J., Edwards, P.J., Hamerský, R., Herzog, F., Klotz, S., Kühn, I., Le Coeur, D., Miklová, P., Roubalova, M., Schweiger, O., Smulders, M.J., van Wingerden, W.K., Bugter, R., Zobel, M., 2008. Plant functional group composition and large-scale species richness in European agricultural landscapes. J. Veg. Sci. 19, 3-14. 
MacEachren, A.M., 1985. Compactness of geographic shape: Comparison and evaluation of measures. Geogr. Ann. 67B, 53-67.

MacQueen, J.B., 1967. Some methods for classification and analysis of multivariate observations. In: Proceedings of Fifth Berkeley Symposium on Mathematical Statistics and Probability, Berkeley, USA, pp. 281-297.

Magurran, A.E., 2004. Measuring Biological Diversity. Wiley-Blackwell, Oxford.

Marshall, E.J.P., 1989. Distribution patterns of plants associated with arable field edges. J. Appl. Ecol. 26, 247-257.

Marshall, E.J.P., 2004. Agricultural landscapes. J. Crop Improvement 12, 365-404

Marshall, E.J.P., 2009. The impact of landscape structure and sown grass margin strips on weed assemblages in arable crops and their boundaries. Weed Res. 49, 107-115.

Marshall, E.J.P., Moonen, A.C., 2002. Field margins in northern Europe: their functions and interactions with agriculture. Agric. Ecosyst. Environ. 89, 5-21.

Moonen, A.C., Castro-Rodas, N., Bàrberi, P., Petacchi, R., 2006. Field margin structure and vegetation composition effects on beneficial insect diversity at farm scale: a case study on an organic farm near Pisa. Landscape Management for Functional Biodiversity WPRS/IOBC Bulletin, 77-80.

Murphy, H.T., Lovett-Doust, J., 2004. Context and connectivity in plant metapopulations and landscape mosaics: does the matrix matter? Oikos 105, 3-14.

O'Neill, R.V., Krummel, J.R., Gardner, R.H., Sugihara, G., Jackson, B., DeAngelis, D.L. Milne, B.T., Turner, M.G., Zygmunt, B., Christensen, S.W., Dale, V.H., Graham, R.L. 1988. Indices of landscape pattern. Landscape Ecol. 1, 153-162.

Oksanen, J., Kindt, R., Legendre, P., Hoara, R.B., Simpson, G., Solymos, P., Stevens, M.H., Wagner, H., 2009. Vegan - Community Ecology Package Project. R package version $1.15-2$

Peet, R.K., 1974. The measurement of species diversity. Annu. Rev. Ecol. Syst. 5, 285-307.

Pignatti, S., 1982. Flora d'Italia. Edagricole, Bologna.

Pignatti, S., Menegoni, P., Pietrosanti, S., 2005. Valori di bioindicazione delle piante vascolari della flora d'Italia: bioindicator values of vascular plants of the flora of Italy. Braun-Blanquetia 39.

Poggio, S.L., Chaneton, E.J., Ghersa, C.M., 2010. Landscape complexity differentially affects alpha, beta, and gamma diversities of plants occurring in fencerows and crop fields. Biol. Conserv. 143, 2477-2486.

Poggio, S.L., Chaneton, E.J., Ghersa, C.M., 2012. The arable plant diversity of intensively managed farmland: effects of field position and crop type at local and landscape scales. Agric. Ecosyst. Environ., http://dx.doi.org/10.1016/ j.agee.2012.01.013.

Quantum GIS Development Team, 2009. Quantum GIS Geographic Information System, http://qgis.osgeo.org. Open Source Geospatial Foundation.

R Development Core Team, 2011. R: A Language and Environment for Statistical Computing. Vienna, Austria.

Raunkiaer, C., 1934. The Life Form of Plants and Statistical Plant Geography. Oxford Univeristy Press, Oxford.

Roschewitz, I., Gabriel, D., Tscharntke, T., Thies, C., 2005. The effects of landscape complexity on arable weed species diversity in organic and conventional farming. J. Appl. Ecol. 42, 873-882.

Schmitz, M.F., De Aranzabal, I., Aguilera, P., Rescia, A., Pineda, F.D., 2003. Relationship between landscape typology and socioeconomic structure: scenarios of change in Spanish cultural landscapes. Ecol. Model. 168, 343-356.

Shannon, C.E., Weaver, W., 1949. The Mathematical Theory of Information. University of Illinois Press.

Sheldon, A.L., 1969. Equitability Indices: dependence on the species count. Ecology 50, 466-467.

Shmida, A., Wilson, M.V., 1985. Biological determinants of species diversity. J. Biogeogr. 12, 1-20.

Simmering, D., Waldhardt, R., Otte, A., 2001. Syndynamics and ecology of Scotch Broom stands in the Lahn-Dill-Highlands (Germany). Tuexenia 21, 51-89.

Simmering, D., Waldhardt, R., Otte, A., 2006. Quantifying determinants contributing to plant species richness in mosaic landscapes: a single- and multi-patch perspective. Landscape Ecol. 21, 1233-1251.

Sosnoskie, L.M., Luschei, E.C., Fanning, M.A., 2007. Field margin weed-species diversity in relation to landscape attributes and adjacent land use. Weed Science Society of America, Lawrence, KS, USA.

Terraltaly, 2007. Immagini TerraItaly TM Digitale - (Compagnia Generale Riprese aeree S.p.A, Parma.

Verburg, P.H., Schulp, C.J.E., Witte, N., Veldkamp, A., 2006. Downscaling of land use change scenarios to assess the dynamics of European landscapes. Agric. Ecosyst. Environ. 114, 39-56.

White, T.A., Campbell, B.D., Kemp, P.D., 1997. Invasion of temperate grassland by a subtropical annual grass across an experimental matrix of water stress and disturbance. J. Veg. Sci. 8, 847-854. 